\title{
FRÖCCSÖNTŐ SZERSZÁM TERVEZÉSE
}

\author{
Topa Martin \\ hallgató, Miskolci Egyetem \\ Gép- és Terméktervezési Intézet \\ 3515 Miskolc, Miskolc-Egyetemváros,e-mail: topa.martin@gmail.com \\ Dömötör Csaba \\ egyetemi docens, Miskolci Egyetem \\ Gép- és Terméktervezési Intézet \\ 3515 Miskolc, Miskolc-Egyetemváros, e-mail: machdcs@uni-miskolc.hu
}

\begin{abstract}
Absztrakt
Az alábbi tanulmány egy fröccsöntö szerszám tervezésének lépéseibe nyújt betekintést. Röviden összefoglalja a fröccsöntési folyamat lépéseit, bemutatja a termékeken végrehajtandó módositásokat a gyárthatóság érdekében. Ezek után a fröccsöntö szerszám betéteinek helyes kialakitását vázolja röviden néhány lépésben.
\end{abstract}

Kulcsszavak: fröccsöntés, müanyag, betét, tervezés, $A B S$

\section{Abstract}

This study gives the reader a deeper inspection to the design method of an injection molding tool. Gives a short summary about the molding and demolding process and the neccessery steps we ought to make in order to make the work pieces more manufactureable. Following these, the study gives some information about the cavity plates design method.

Keywords: injection molding, mould, mold, ABS, plastic, design, method

\section{Fröccsöntési technológia bemutatása}

A fröccsöntési technológiát napjainkban 2 fö részre lehet osztani. Az első a müanyag fröccsöntés a második a fémfröccsöntés. Alapvetően a két módszer megegyezik, azzal a kivétellel, hogy müanyagok esetén nem szükséges a darabokat utólag hőkezelni (a szerszámból kiérkező késztermék miután szobahőmérsékletig hült már használható is).

\subsection{A mủanyag fröccsöntő technológia}

A polimerek feldolgozásának egyik legfontosabb módja a fröccsöntés, mivel képesek vagyunk bonyolult geometriájú termékek elóállítására is ilyen módon. Előnyei, hogy majdnem teljesen hulladékmentes, hiszen a folyási utakhoz használt müanyag legtöbbször bizonyos részben visszatáplálható a rendszerbe, elkeverve a granulátummal, újra fel lehet használni. Forrócsatornás rendszer esetén pedig jelentősen csökkenthetjük a folyási utakhoz felhasznált müanyagot is. Az extrudáláshoz hasonlóan a fémek sajtolásából jött létre ez a technológia is. Nagy pontosságú eljárás, mégis képesek vagyunk pár grammos termékektöl akár nagyobb kádak vagy utcai kukák öntésére is, 
így a mérettartomány igen széles. A folyamat során feldogozott polimerek lehetnek mind hőre lágyuló mind hőre keményedőek. A legáltalánosabbak a PE (polietilén), PS (polisztirol), PVC (poli-vinilklorid), ABS (akrilnitril-butadién-sztirol) és a PC (polikarbonát).

A fröccsöntés alapvető elve az, hogy az olvadt müanyagot melegítve kis viszkozitású folyadékállapotba hozzuk, majd nagy sebességgel egy formaadó üregbe injektáljuk. Itt hagyjuk kihülni, és zsugorodás után kialakul a kívánt alkatrész. Így kapunk egy termelékeny és nagy pontosságú képlékenyalakító eljárást.

\subsection{Fröccsöntési folyamat leírása}

Szerszámzárás: A folyamat a szerszám zárásával veszi kezdetét. Ebben a szakaszban a szerszám lapjai összezárnak, kezdetben nagy sebességgel, de a lapok találkozása előtt hirtelen lelassul a folyamat, ezzel is védve azokat a károsodástól és csökkentve a ciklusidőt.

A fúvóka előre mozgatása: Ebben a szakaszban a gép fúvókája előre mozdul a központosító gyűrűvel való találkozásig.

Meglövés: A meglövés során a csigadugattyú nagy sebességgel juttatja az olvadt granulátumot a formaadó üregbe. Eddig a pontig a granulátum a tartályból adagolva került a csigahengerbe, ahol fütőtestek gondoskodnak annak megfelelő hőmérsékletre való hevítéséről. Ezt a melegítést segíti a csigában lezajló súrlódás is. Az anyag a formába juttatása után utónyomást alkalmazunk. Erre azért van szükség, mert a polimer olvadt állapotban lényegesen nagyobb fajtérfogattal rendelkezik, mint megszilárdultan. Fontos megvizsgálnunk ilyenkor, hogy a szerszám teljes mértékben ki legyen töltve, illetve a folyamat során fellépő zsugorodással is számolnunk kell.

Hülés/hütés: Miután teljesen sikerült kitölteni az üreget és alkalmaztuk a megfelelő utónyomást, hagynunk kell időt a hülésre. Ezt általában a szerszámba épített hütőkörök alkalmazásával gyorsítják fel.

Plasztikálás: A hütéssel párhuzamosan zajló folyamat, amikor a csiga forogni kezd. A csigahengerben lezajlódó súrlódás és a fütőtestek által átadott hő hatására a granulátum megolvadt állapotba kerül készen a következő ciklusra.

\section{Fúvóka hátra mozgatása}

Abban az estben, ha túl nagy a ciklusidőnk megvan a veszélye, hogy a fúvóka végében lévő ömledék megdermed ezzel elzárva a meglövési utat, esetleg félig dermedt anyagot juttathatna a következő ciklus alatt a szerszámba, ezzel okozva hibás termékeket. Ezért nagy ciklusidők esetén hátra kell mozgatni a fúvókát és elzárni annak végét.

\section{Szerszámnyitás}

A hủlési idő, illetve plasztifikálás végeztével a szerszám nyit, ekkor kidobók vagy kilökők gondoskodnak a termék kijuttatásáról. A lapok szétválnak.

\section{Kidobás}

A szerszám nyitásával a termékünk kipottyan, nagyjából használatra készen. 


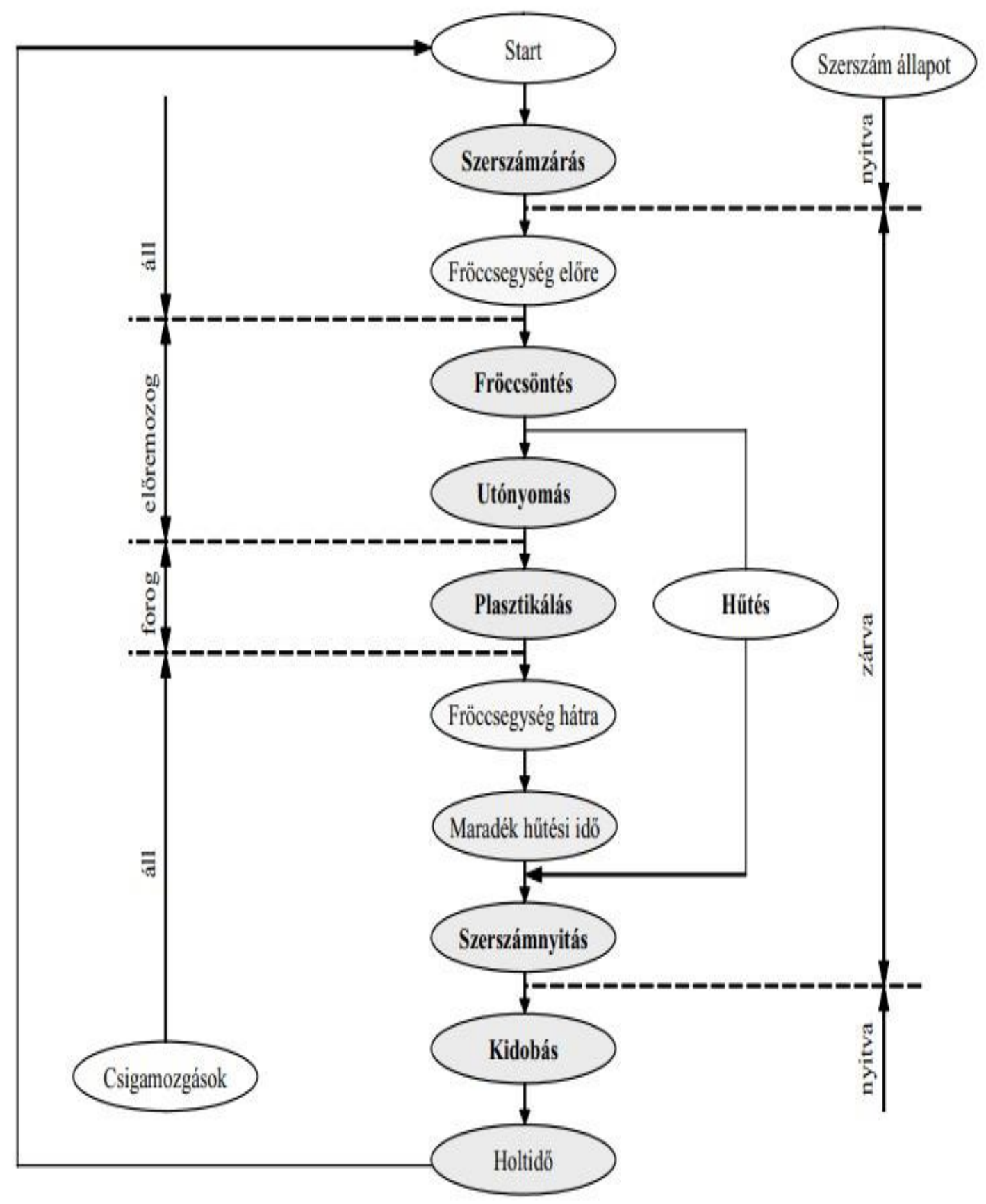

1. ábra. Fröccsöntési folyamat lépései [12] 


\section{2. Általánosságok az ABS-ről}

Egy ipari feladat során majdnem minden esetben meg van szabva a tervező számára a műanyag, amelyet fel akarnak használni a fröccsöntéshez. Ez jelen esetben ABS. Az ABS vagyis az akrilnitrilbutadién-sztirol egy jó ütésálló képességgel, nagy keménységgel és szilárdsággal, jó hőállósággal és vegyszerállósággal rendelkező hőre lágyuló mủanyag. [1] Fő tulajdonságait 3 alapvető alkotóelemének köszönheti. A sztirol biztosítja a jó feldolgozhatóságot. Az akrilnitril a keménységet, hőállóságot és kémiai elillanását. A butadién pedig a rugalmasságot és az alacsony hőmérsékleten való keménységet. Felhasználása -20 és $+80 \mathrm{C}^{\circ}$ között ajánlott. A manapság elterjedtnek mondható 3D-s nyomtató technológiák is alkalmazzák, de legföképp extrudálással vagy fröccsöntéssel dolgozzák fel. Felhasználják többek közt autóipari alkatrészeknek, burkolóelemeknek, háztartási eszközök házaként, elektronikai eszközökhöz vagy éppen a LEGO kockákhoz.

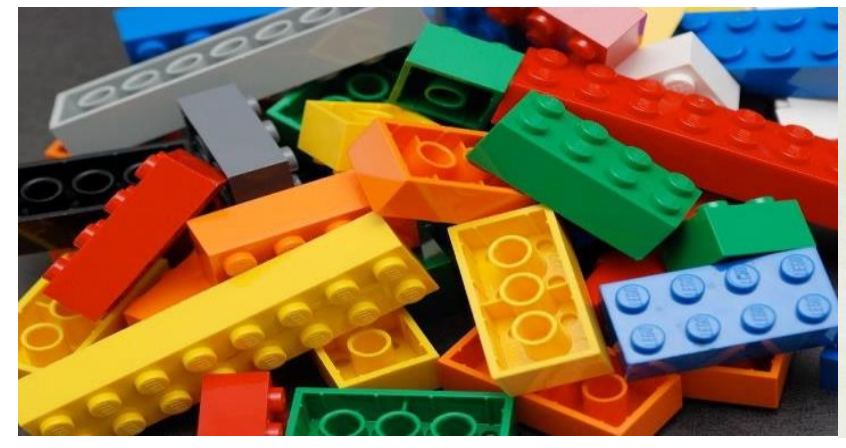

2. ábra. LEGO ABS-böl [1]

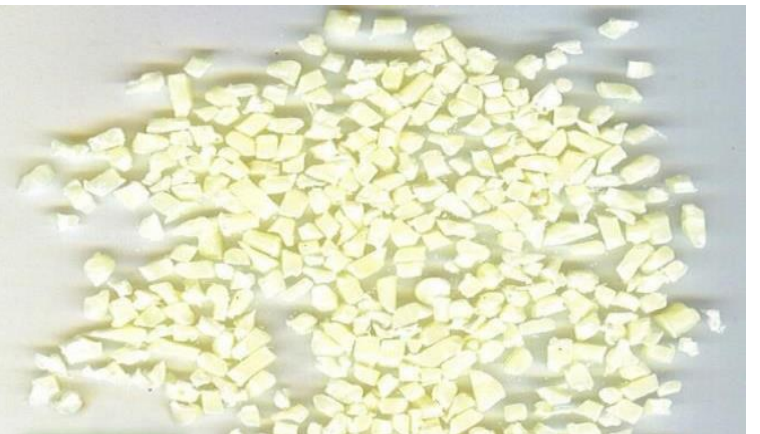

3. ábra. ABS granulátum [1]

\subsection{Az ABS fö tulajdonságai a fröccsöntés szempontjából}

Fontos ismernünk a gyártani kívánt termék anyagának főbb tulajdonságait még a tervezés megkezdése előtt azért, hogy kialakíthassuk a legmegfelelőbb koncepciót a szerszámunknak.

Ilyen tulajdonság például a zsugorodás, amely az ABS re jellemző 0,3\%-0,7\%-ig terjed. A későbbiekben számolhatunk nagyjából 0,5\%-os zsugorral, amennyiben nincs igény külön „steelsafe” eljárásra. A következő ilyen tulajdonság a minimális és a maximális falvastagság. A legkisebb falvastagság ebből a mủanyag termékből mára már $0,2 \mathrm{~mm}$, míg a legvastagabb fal, amit sikeresen öntöttek eléri a 7mm-t-is. A megkívánt falferdeség tekintetében is igen jó anyagnak tekinthető, hiszen akár bármilyen ferdeség nélkül is fel lehet dolgozni. Ez ugyan nem ajánlott, mivel ebben az esetben sokkal nehezebb a darabok eltávolítása, így érdemes egy $0,5^{\circ}$ és $1^{\circ}$ közötti ferdeséget adni a falaknak. Ajánlott lekerekítéseket nézve a minimum megkívánt lekerekítés a falvastagság negyede. A maximális ajánlott lekerekítés a falvastagság 60\%-a. Az ABS egy kis zsugorral rendelkező stabil amorf anyag, így viszonylag kis türésekkel is képesek vagyunk nagy mennyiségben gyártani. Jó a reprodukálhatósága, habár extrém nagy falvastagság igénye esetén ezek a türések igencsak megnőhetnek, épp úgy, mint a hülési idő és a ciklusidő. Az összecsapásokra (azok a helyek, ahol az olvadt müanyag szétválik majd ismét összetalálkozik, így varrat képződik) is igénytelennek tekinthető, mivel ezek a helyek legtöbbször szabad szemmel nem láthatóak és nem okoznak túl nagy gondot a szerkezeti felépítésben sem. Meglövési pont megválasztási esetén érdemes a meglövést követően az 
anyagot egyből egy falnak irányítani vagy eltéríteni és nem teljesen végigfolyatni a formaüregben hosszirányban.

\section{Geometriai módosítások}

Fröccsöntő szerszámok tervezésénél figyelembe kell vennünk a gyártani kívánt termék geometriáját és módosítani azt a gyárthatóság érdekében. Ezeket a módosításokat ipari körülmények között mindig egyeztetni kell a megrendelővel és csak utána tovább haladni a tervezéssel.

Az alábbi képek az általam gyártani kívánt termék CAD modelljének képei, módosítások előtt, illetve után.

A termék geometriájának kialakításakor már gondolnunk kell a szerszám osztására és aszerint az addig egyenes falaknak ferdeséget adni. Ez jelen esetben a termék oldalfalait érintette. Az ABS-ből készült termékeknek más-más szakirodalmak más-más értékeket ajánlanak, de általában $1^{\circ} \sim 0,5^{\circ}$ között, így én az oldalfalaknak egy $0,5^{\circ}$-os falferdeséget adtam, belül és kívül is a szerszám későbbi kialakításának megfelelően. A falferdeségek helyes megadása rendkívül fontos számunkra, mivel ha ezt a lépést rosszul adjuk meg nem csak, hogy a munkadarabunk nem fog kijönni a formaüregböl, de a darabunk alámetszetté is válik egyúttal.

Fontos figyelnünk az egyenletes falvastagságra és az éles sarkok elkerülésére, így további lekerekítéseket kell alkalmazni a modellen. Szakirodalmak alapján ez 0,25-0,6-szoros értéke a falvastagságnak. Figyelnünk kell az alámetszések elkerülésére, persze ezekre a korszerü CAD programok figyelmeztetnek is, ez jelen esetben nem volt probléma.

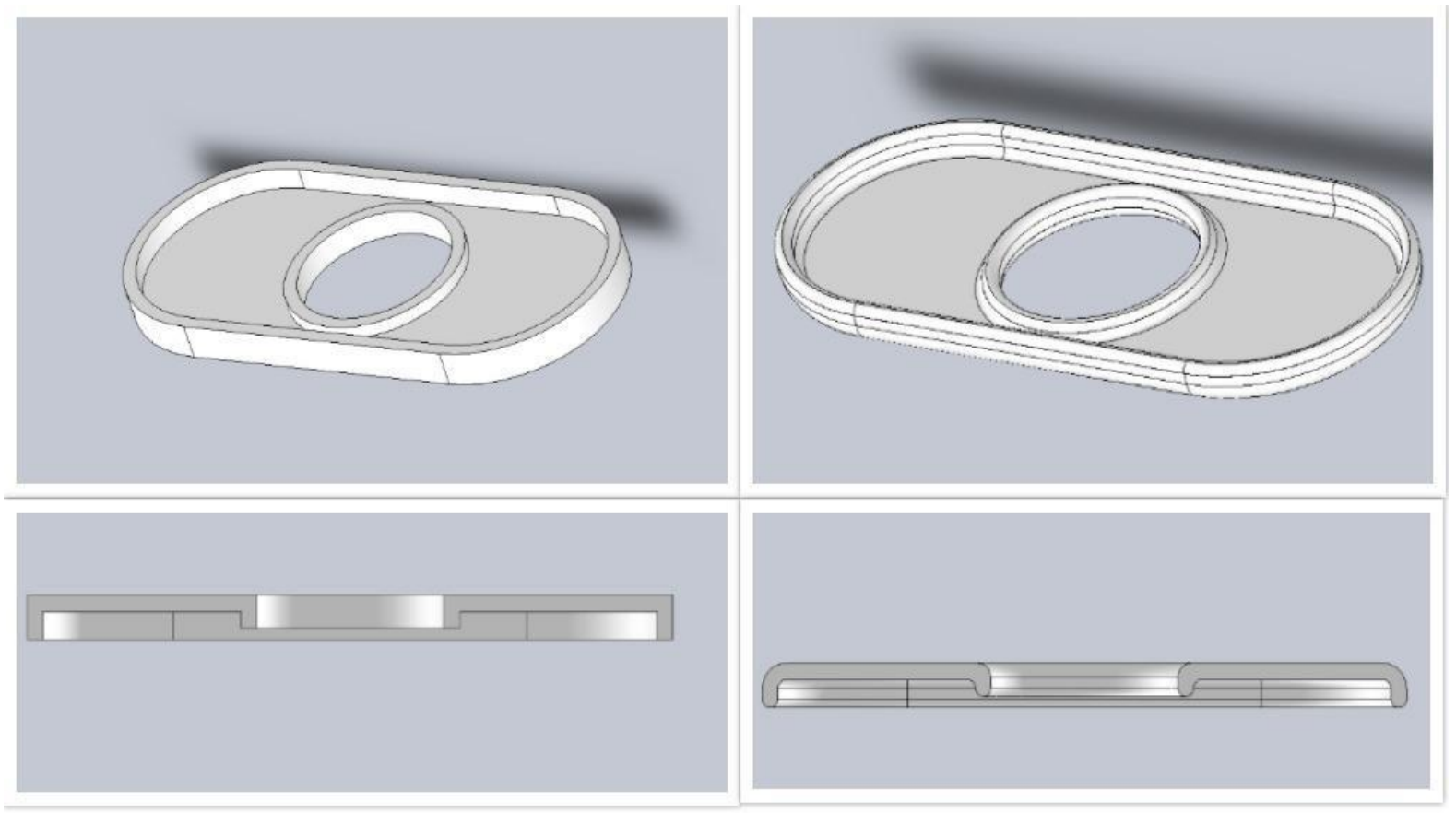

4. ábra. CAD modell módositás elött (bal) illetve után (jobb) 


\section{Szerszámüreg kialakítása}

A szerszámüreg és ezzel együtt a betétek (sok elnevezést használnak ezekre kortól és szakirodalomtól függően például mag, illetve csésze betét vagy kidobó oldali és beömlő oldali betét) kialakításának első lépése a termék gondos és hosszantartó tanulmányozása után, az osztósík megválasztása.

\subsection{Osztósík megválasztása}

Az osztósík az a sík, ahol a beömlő oldali és a kidobó oldali betétek találkoznak, itt zár össze a két szerszámfél. Az osztósíkot úgy kell megválasztanunk, hogy a termék hülés során gyakorlatilag rázsugorodik a betétekre és ez után a nyitás során lehetőleg a kidobó oldali, mozgó szerszámfélen maradjon. Ennek a szempontnak megfélően kell a falferdeségeket megadni úgy, hogy a termék ne legyen alámetszett és minél könnyebben eltávolítható legyen a szerszámból kidobás során.

Az osztósík megválasztásánál még azt is szem előtt kell tartanunk, hogy ezen a síkon lesz legvalószínűbb a sorjaképződés. Tehát lehetőleg úgy legyen kiválasztva a síkunk, hogy később utómunkánál amennyiben sorja képződik az könnyen eltávolítható legyen.

A korszerủ CAD tervező rendszerek (például SolidWorks) külön erre a célra ellátott modullal rendelkeznek szerszámtervezők számára. Így a "draftanalysis" parancs segítségével és a kilökés irányát megadva gyerekjáték az osztósík megválasztása, mint az alábbi ábra is mutatja.

Az ábrán piros szín jelzi a munkadarabon a kidobó oldali betéttel érintkező részeket míg zöld a beömlő oldalival érintkezőeket.

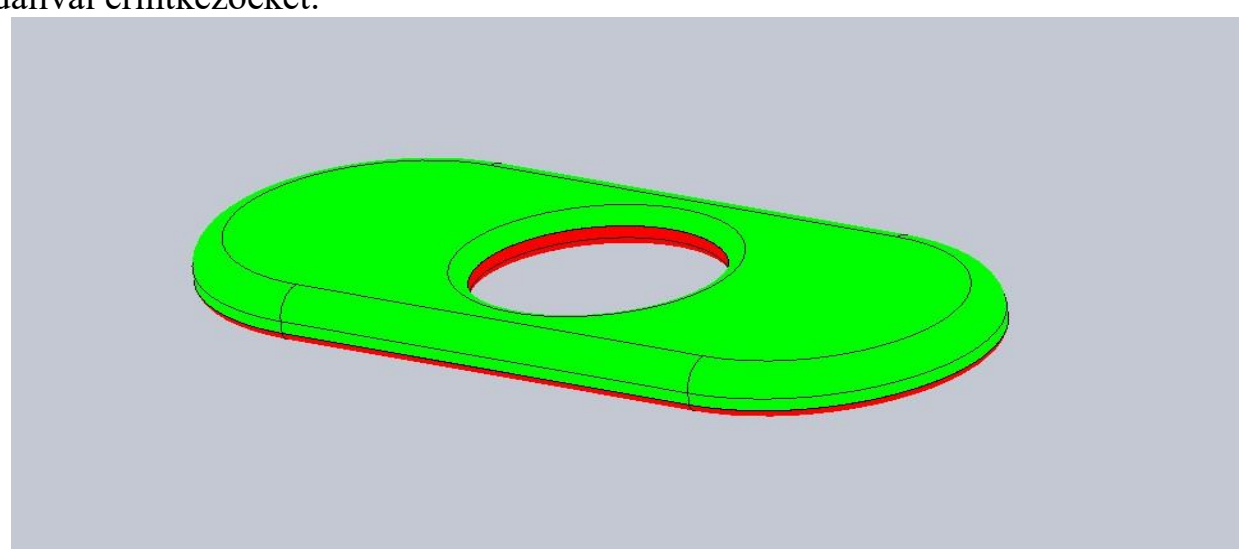

5. ábra. Osztósík megválasztás SoldiWorks Mold Tools modul segitségével

\subsection{Zsugor}

A tervezés során az egyik kritikus pont a zsugor helyes megadása és az azzal való számítások. Fröccsöntés során minden múanyag termék zsugorodik, vagyis hibát követnénk el, ha a szerszám betétéit pont úgy alakítanánk ki, hogy azok méretei megegyezzenek a késztermék méreteivel.

A teljes zsugorodás három fő részből áll, mivel a műanyagot magas hőmérsékleten injektáljuk a formaüregbe így annak lehülése és megszilárdulása közben jelentősen csökken a térfogata, ezzel párhuzamosan a fém lapok felmelegednek és tágulnak, de a kidobás után a termék még tovább hül szobahőmérsékletig így méretei még ekkor is csökkennek és ezzel számolnunk kell. A szerszám 
méretei ezen három tényező összeségeként kapható meg. Fontos megemlíteni, hogy régebben külön definiáltak térfogati és lineáris zsugorodást és a méreteket ezek szerint számoltak, leginkább lineáris zsugorodással az egyszerüség és praktikusság miatt. Manapság elég egy egyszerű „scale” parancsot alkalmaznunk és megkaphatjuk a kívánt méreteket az anyagra jellemző értékek ismeretében. Ez jelen esetben az ABS-re jellemző 0,5\%, így a szerszám betétéit úgy kell kialakítani, mintha a gyártani kívánt termék méretei az eredetinek 100,5\% lennének.

\section{Gát és meglövési pont megválasztása}

Az alakadó fészkekbe beérkező nagy nyomású és magas hőmérsékletű müanyag olvadék a gáton keresztül jut be. A gát gyakorlatilag egy gyorsan szükülő keresztmetszete az elosztócsatornáknak. Hogyha közvetlenül a beömlő csatorna vagy az elosztócsatorna torkollana a formaadó üregekbe, akkor a csatornamaradék és a munkadarab szétválasztása igen körülményes lenne és nem igazán lehetne nyomtalanul szétválasztani őket. A gátnak egy másodlagos funkciója az olvadt mủanyag további melegítése, hiszen a gyorsan szúkölő keresztmetszetben az olvadék és a szerszám közti súrlódás megnő ezzel hőt termelve.

\subsection{Gát típusok}

A gátak végződése szerint két kategóriába csoportosíthatjuk. Az egyik a szükülő végződésủ a másik a táguló végződésü. A kettő közti lényeges eltérés, hogy szükülő végződés esetén (a) a munkadarabból szakítunk ki anyagot az elválasztás során. A munkadarab felületén egy üreg képződik. Táguló végződés esetén (b) a csatornamaradékból szakítunk ki anyagot, így egy kitüremkedés lesz észrevehető a munkadarabunk felületén.
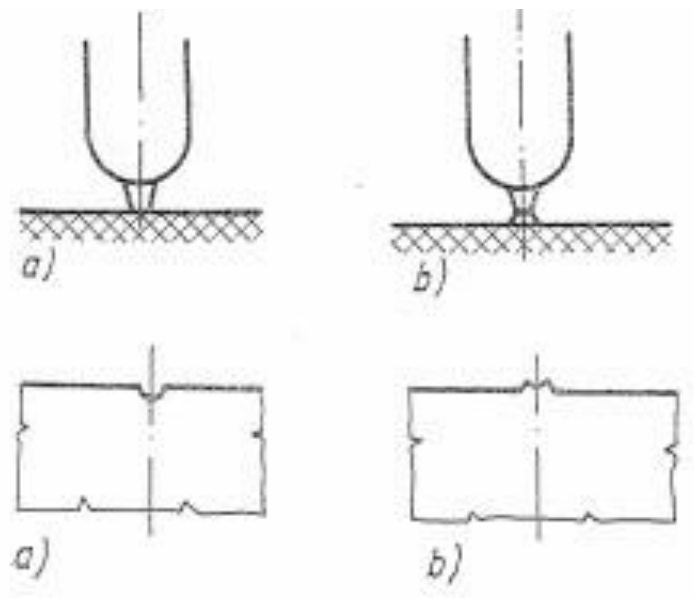

6. ábra. Gátvégződések [6]

Meglövésként definiálhatjuk azt a folyamatot, amikor a gát gyorsan szükülő keresztmetszetéhez ér az anyag majd hirtelen, lövésszerüen a formaüregbe áramlik. Ez a pont a meglövési pont. A gátakat felépítésük szerint is külön kategóriákba oszthatjuk. Ilyen kategória például: 


\subsubsection{Direkt meglövés}

Habár itt nem alkalmazunk gátat, fontos megemlíteni, mint lehetséges opciót. Direkt meglövés alkalmazása egyfészkes szerszámoknál történhet, abban az esetben, ha a gyártani kívánt termék körszimmetrikus, így a müanyag egyenletesen tud áramlani a meglövési ponttól a formaüreg minden pontja felé. leginkább vastag falú termékek esetén van létjogosultsága, ha nem számít az esztétikai minőség, mivel a beömlés helye később jól látható nyomot fog hagyni a darabunkon. A csatorna eltávolítása később kisebb-nagyobb darabokat fog belöle kitépni vagy éppen fordítva, a csatorna egyes darabjai úgy törnek le, hogy azok még a termékünkön maradnak, bár ezt utómunkával el lehet távolítani.

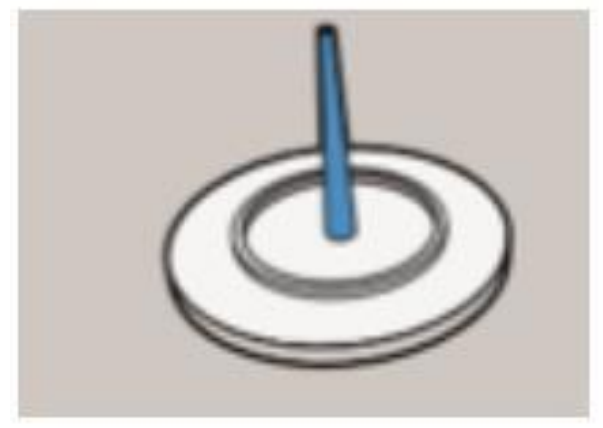

7. ábra. Direkt meglövés [12]

\subsubsection{Standard gát}

Standard gátmeglövés többfészkes szerszámok esetén indokolt, ha nincs semmilyen kritérium a darabbal szemben és könnyen gyártható szerszámot szeretnénk megalkotni.

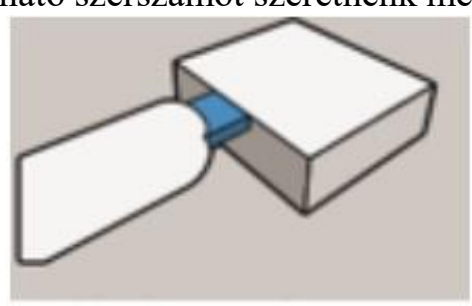

8. ábra. Standard gát [12]

\subsubsection{Film vagy legyező gát}

Főként lapos, inkább kétdimenziósnak mondható darabok estén javasolt a használata

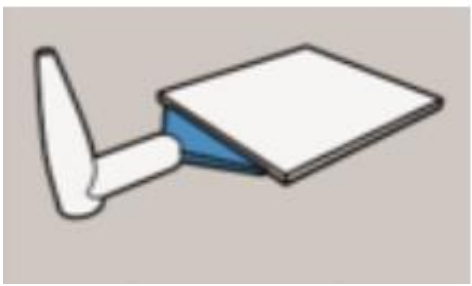

9. ábra. Legyezö gát [12] 


\subsubsection{Alagút gát}

Az alagútgátak az egyik leggyakrabban használatos típusok hidegalakító szerszámok esetén mivel szerszámnyitás során automatikusan eltávolítható a csatornamaradék így a munkadarab már szétválasztva esik ki gépünkböl.

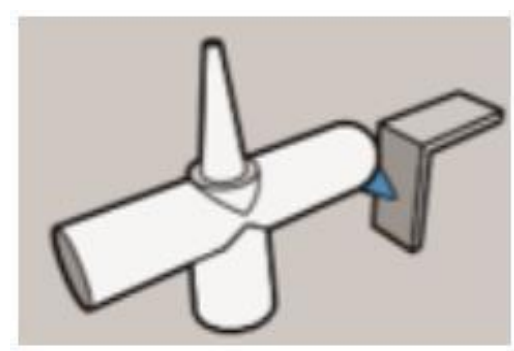

10. ábra. Alagút gát[12]

\subsection{Gátválasztás}

Figyelembe véve az egyszerüséget, a gyárthatóságot és a termelési szempontokat a legideálisabbnak tünő megoldás a banán gát, hiszen ez rendelkezik a legtöbb pozitív tulajdonsággal (beleértve az esztétikai tulajdonságokat is) könnyen beszerezhető és még talán csökkenti is a szerszám megmunkálásának idejét, de mindenesetre nagyban meggyorsítja a termék gyártását, és csökkenti az egy termékre jutó költségeket.

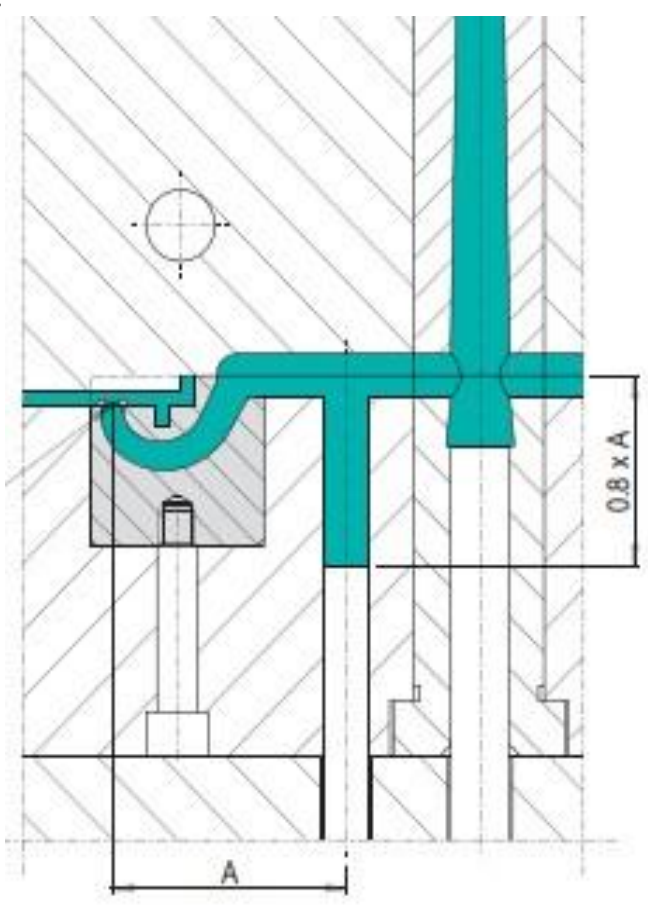

11. ábra. E16935 Meusburger gát [14] 
Fontos megjegyeznünk, hogy az általunk katalógusból megvásárolt gát még egyből beépítésre nem alkalmas, hiszen ezen is kell kisebb utómunkákat végezni, de ez kimerül egyszerü marási és tömbszikraforgácsolási műveltekben. Ezekre a müveltekre a Meusurger katalógusban megfelelő mennyiségü és minőségű ajánlást kapunk természetesen. Illetve a gát elhelyezését illetően is megkapunk minden szükséges információt beleértve a kidobáshoz szükséges pinek elhelyezését és méretét is. Meusburger katalógus alapján az ideális választás az E 16935_18 jelü gát.

\section{Fészekszám meghatározása}

A szerszámunkat egy LOG 210/s8-A típusú géppel szeretnénk üzemeltetni, ennek adatai legtöbbször a gyártó oldalán megtalálhatóak. A fészekszám meghatározása során figyelembe kell vennünk a szerszámgépünk elméleti fröccsöntési teljesítményét és annak méreteit. Az elméleti fröccsöntési térfogat jelen esetben $381 \mathrm{~cm}^{3}$. A gyártani kívánt elemünk $2.51 \mathrm{~cm}^{3}$. A két szám hányadosaként máris megkaphatnánk a fészkek számát, de ezzel hibát követnénk el, mivel egy irreálisan nagy 150 fészkes szerszám tervezéséhez fognánk.

Érdemes nem a teljes fröccsöntési teljesítményt figyelembe venni, csupán ennek 60-70\%-át a maradék 30-40\%-ot pedig „tartalékként kezelni”. Ezen kívül a gyártás során hidegcsatornás szerszámnál a fröccsöntési térfogat nem csak a formaüregek kitöltésére fordítódik, hanem az elosztó és beömlő csatornák megtöltése is, illetve egy kisebb mennyiség a gátakra. A fészekszám általában 2 vagy annak valamelyik többszöröse az elosztócsatornák és a betétkonstrukció függvényében persze más kialakításokban is gondolkodhatunk, de maradjunk csak a folyamatosan kétfelé ágazó csatornáknál. Az így kapott lehetséges fészekszámok 2-4-8-16-32-64, mivel több már biztosan nem férne el a gépen. A biztonság kedvéért számoljunk a csatornákat kitöltő müanyag térfogatával mintha az a formaüregek térfogatával lenne megegyező. Így tehát 1 termékhez nagyjából $5 \mathrm{~cm}^{3}$ szükséges. A rendelkezésre álló térfogat pedig $230 \mathrm{~cm}^{3}$.

Ezen két szám hányadosa egy 45 fészkes szerszámot sugall, de persze mi a kettő valamelyik többszörösével szeretnénk dolgozni így a 32 fészkes szerszám lenne az ideális választás.

A tervezés későbbi lépéseiben ez az elképzelés túl nagynak bizonyult, mivel méreteiben olyan nagy szerszámot kapunk, ami már nem fér fel a gépünkre, így 16 fészek lett a végső konstrukció. Ez azzal jár, hogy a kihasználható fröccsöntési térfogat jóval nagyobb, mint a szükséges, de így nyugodtak maradhatunk, hiszen bőven elegendő tartalékot hagytunk a gépünkben, habár ennek gazdaságossági következményei lesznek, de ezekkel nem célja foglalkozni a szakdolgozatomnak.

\section{Elosztócsatornák}

Többfészkes szerszámoknál az elosztócsatornák és a fészkek elrendezését többféle elv alapján is elvégezhetjük. A csatornarendszerünk lehet természetesen, mesterségesen vagy vegyesen szabályozott. Természetes szabályozásról beszélünk, hogyha minden fészekhez azonos hosszú és keresztmetszetü (egymáshoz képest) folyási úton juthat el ez ömledék. Mesterséges szabályozásról akkor beszélhetünk, ha a csatornák keresztmetszeteivel kompenzáljuk a különböző folyási utak hosszát, így érve el, hogy a minden üreg kitöltése azonos időben zajlódjon. Mivel a természetes szabályozás egy biztos és egyszerübb döntés, így használjuk ezt. 


\section{A csatornák tervezése során fontos szempontok:}

Az elosztócsatornák lehetőleg körszelvényüek legyenek, csak nagyon jól folyó anyagok estén engedhető meg a félkör vagy trapéz keresztmetszetủ csatorna, vagy ha a gép nyomóteljesítménye jóval nagyobb, mint a szükséges. Ez tehát számunkra azt jelenti, hogy bármely keresztmetszetet nyugodtan használhatjuk a bőséges tartalékteljesítményünk révén.

Az elosztócsatornák a lehető legkevesebb irányváltoztatást tartalmazzák, és a lehető legrövidebb úton juttassák az ömledéket a formaüregekbe. Az elosztócsatornák induló keresztmetszete, akkora legyen, mint a beömlőcsatorna végső keresztmetszete. A formaüregek megtöltése és lepecsételödése azonos időben történjen.

Hosszú csatornák ne torkoljanak egyből a betétekben, alkalmazzunk lencséket, hogy a túlmelegedett, esetleg már elszíneződött anyag ne kerüljön a munkadarabunkba.

A 12. ábra különböző elosztócsatorna elrendezéseket mutat. Az „a-b” elrendezés nem megfelelö, hiszen az elosztócsatornák hossza az üregekig igen változó, ezt legfeljebb mesterségesen a csatornakeresztmetszetek gondos megtervezésével lehet orvosolni. A „,c" ábra szintén helytelen, mivel indokolatlanul sok csatornamaradék keletkezne, ezt orvosolja az „e” ábra.

$\mathrm{Az}$,e-g” ábrákon a jó megoldásokat láthatjuk és az „f” 16- fészkes megoldás tökéletes választás számunkra, a későbbiekben a folyási utakat ez alapján érdemes megtervezni a CAD modellben. Fontos megjegyeznünk, hogy habár természetes szabályozást használunk az elágazások után, mégis érdemes szükíteni a keresztmetszeteket, úgy, hogy a gáthoz érve elérjük az általunk kívánt 3,4mm-es átmérőt (a beépített gátnál). Így a megtervezett csatornák a beömlés (12mm átméröjü) felől fokozatosan csökkennek 6-54-3,5 -mm-ekre (a beömlö csatornától a gát irányába elágazásonként csökkentve), így alkotnak úgynevezett ,szabályos csatorna méretláncot”.

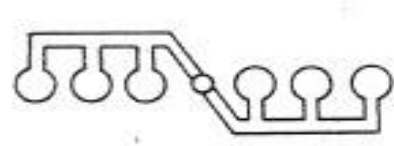

a)

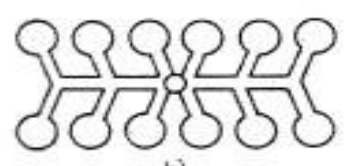

b)

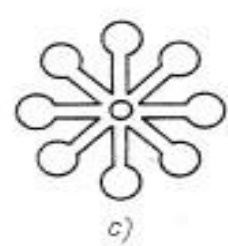

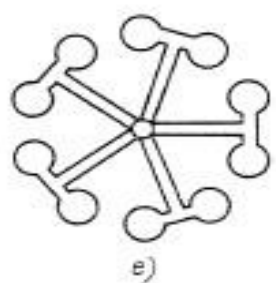

e)

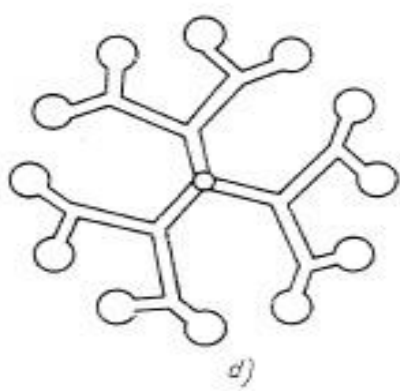

d)

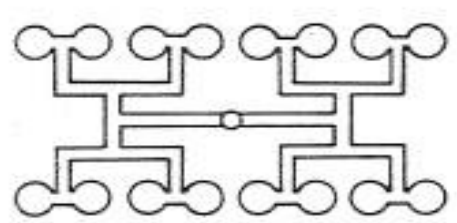

g)

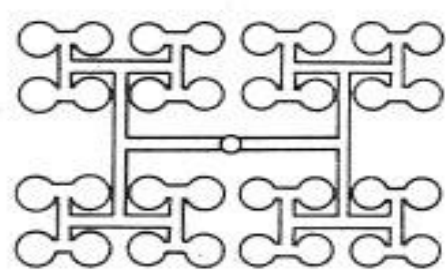

f)

12. ábra. Elosztócsatornák elrendezése [7] 
A betétek ismeretében már csak a szerszámházat és a kidobó rendszert kell megterveznünk ehhez a szerszámgyártó nagycégek (HASCO Meusburger) bőségesen elegendő információt biztosítanak. Katalógusok felhasználásával és szabványos elemekkel és normáliák felhasználásával gyorsíthatjuk a tervezést.

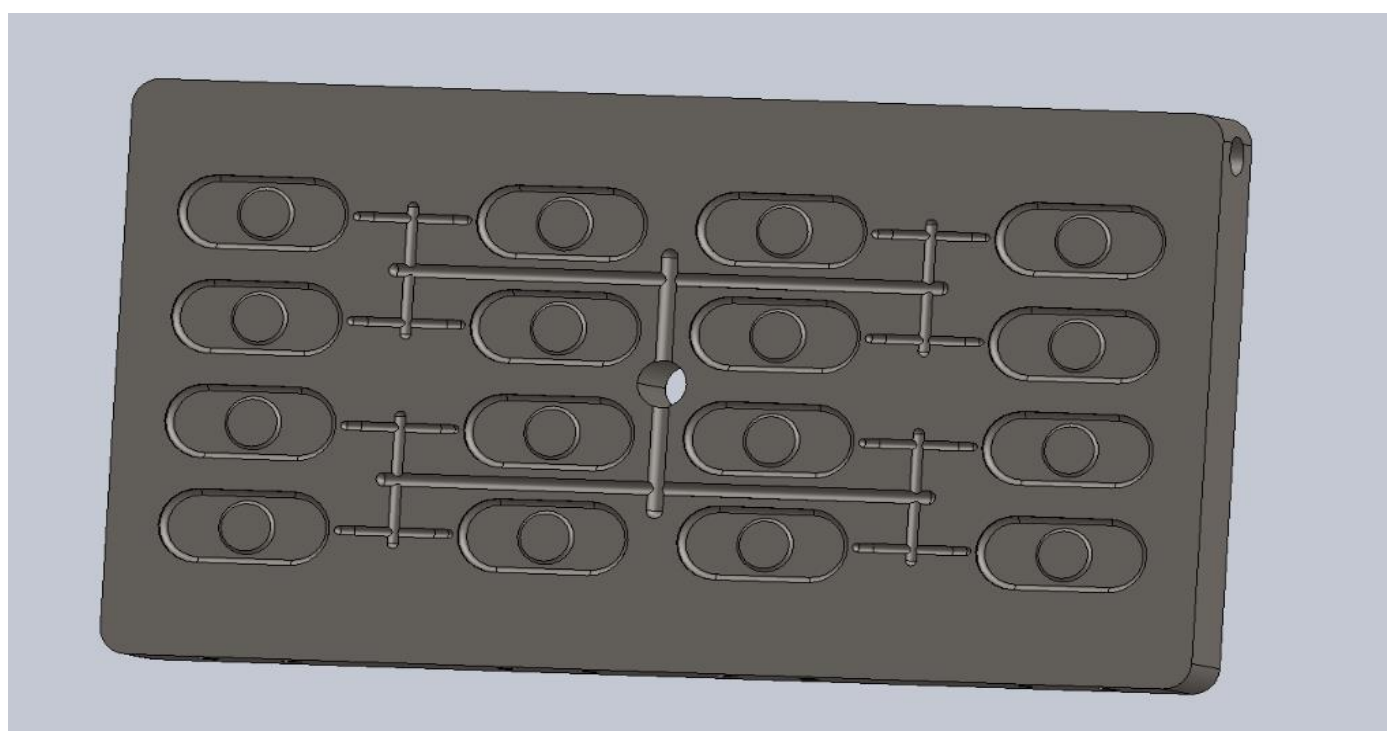

13. ábra. A 16 fészkes beömlö oldali betételrendezés elosztócsatornákkal

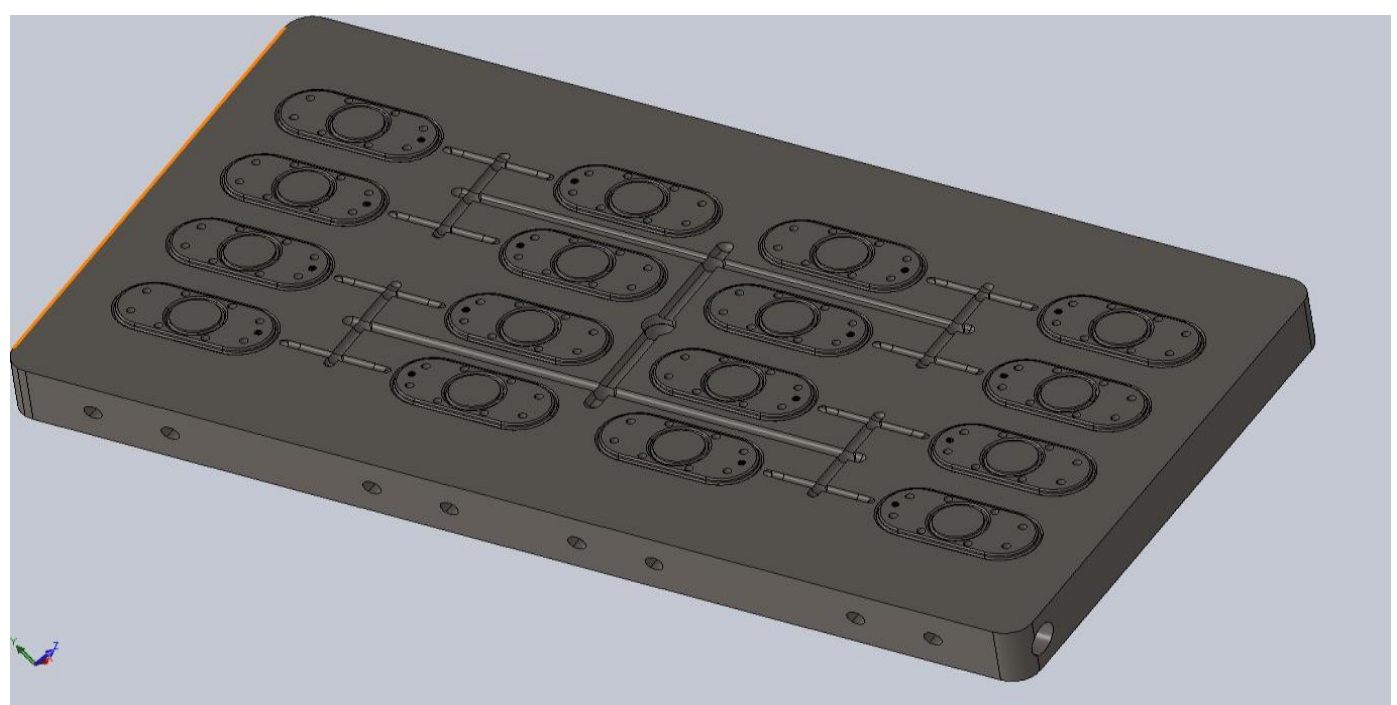

14. ábra. A 16 fészkes kidobó oldali betételrendezés elosztócsatornákkal, hütöfuratokkal, gátakkal és a kidobóknak szánt helykialakitással ellátva 


\section{Köszönetnyilvánítás}

A cikkben ismertetett kutató munka az EFOP-3.6.1-16-2016-00011 jelủ „Fiatalodó és Megújuló Egyetem - Innovatív Tudásváros - a Miskolci Egyetem intelligens szakosodást szolgáló intézményi fejlesztése" projekt részeként - a Széchenyi 2020 keretében - az Európai Unió támogatásával, az Európai Szociális Alap társfinanszírozásával valósul meg.

\section{Felhasznált irodalom}

[1] Akrilnitril-butadién-sztirol: https://hu.wikipedia.org/wiki/Akrilnitril-butadién-sztirol

[2] ABS tulajdonságai https://www.plasticstoday.com/thermoforming/design-designing-abs/5828825362675

[3] Fröccsöntés: https://hu.wikipedia.org/wiki/Fr\%C3\%B6ccs\%C3\%B6nt\%C3\%A9s

[4] Fém Fröccsöntés: https://www.carbolite-gero.hu/hu/alkalmazasok/hokezelesi-alkalmazasok/femmim-es-keramia-cim-froeccsoentes/

[5] Log-katalógus: https://www.log-machine.com/uploads/1515635237765.pdf

[6] Sors, L., Bardócz, L., Radnóti, I.: Mủanyagalakító szerszámok. Müszaki Könyvkiadó, 1970. ISBN: 9631016986

[7] Kovács, J., Vincze, Á.: A képlékenyalakítás szerszámai, Müszaki Könyvkiadó, 1981. ISBN: 9631035867

[8] Sors, L.: Zsebszámológép programok - Mủanyagalakító szerszámok tervezése, Müszaki Könyvkiadó, 1984. ISBN: 9631058409

[9] Kovács, J.G.: Fröccsöntött termékek tervezése és szimulációja. https://repozitorium.omikk.bme.hu/bitstream/handle/10890/556/ertekezes.pdf?sequence=1

[10] Kavalecz, T.: Fröccsöntött müanyag alkatrészek technológiai és szerszámtervezése CAE alkalmazással. http://midra.uni-miskolc.hu/document/30189/26156.pdf

[11] ABS Mechanikai tulajdonságai: https://ultimaker.com/download/67625/TDS\%20ABS\%20v3.011-hun.pdf

[12] Virág, Á.: Fröccsöntő szerszám tervezése http://midra.uni-miskolc.hu/document/32954/29055.pdf

[13] Kazmer, D.: Injection Mold Design Engineering, Hanser Kiadó München, 2016. ISBN: 9781569905708

[14] Meusburger katalógus: https://ecom.meusburger.com/index/index.asp?rnd= 